\title{
Manajemen Pembelajaran Al-Qur'an: Studi Kasus Longitudinal di Pondok Pesantren
}

\author{
Rosyida Istiqomah*, \& Reni Lailina Hidayah \\ UIN Maulana Malik Ibrahim Malang, Indonesia \\ Jl. Gajayana no. 50, Dinoyo, Kec. Lowokwaru, Kota Malang, Jawa Timur \\ Email: rosyidaistiqomah99@gmail.com
}

\begin{abstract}
Many studies on management have been carried out, but leading to the learning of the Qur'an in Islamic boarding schools have not been found. This study aims to analyze the management of al-Qur'an learning at the Islamic Boarding School. Using a case study approach with data collection techniques, namely interviews with pesantren leaders, teachers, and students, and analyzed by data reduction, presentation and drawing conclusions and verification. The results of the study found that the Pesantren Bahrul Ulum Tangsil Kulon Bondowoso had a systematic management of learning the Qur'an. First, the activities of planning the learning of the Qur'an were followed by all teachers. There is a grouping of students in certain classes according to the level of ability. Second, there is a clear organization, so that it helps each component to work according to the authority and responsibility in learning the Qur'an. Third, in the implementation of learning the Qur'an there is a different treatment in each class, so as to maximize the ability of students. Fourth, the evaluation of al-Qur'an learning is carried out thoroughly, not only looking at learning outcomes but also the learning process takes place. The implication of this research is on the development of "al-Qur'an learning management theory" in the treasures of Islamic education.
\end{abstract}

Keywords: Management, Learning Management, Al-Qur'an Learning, Boarding School.

Abstrak: Penelitian tentang manajemen telah banyak dilakukan, namun mengarah pada pembelajaran al-Qur'an di pondok pesantren belum ditemukan. Penelitian ini bertujuan menganalisis manajemen pembelajaran al-Qur'an di pondok pesantren. Menggunakan pendekatan studi kasus dengan teknik pengumpulan data adalah wawancara terhadap pimpinan pesantren, guru, dan siswa, serta dianalisis dengan reduksi data, penyajian dan penarikan kesimpulan serta verifikasi. Hasil penelitian menemukan bahwa pesantren Bahrul Ulum Tangsil Kulon Bondowoso memiliki manajemen pembelajaran al-Qur'an yang sistematis. Pertama, kegiatan perencanaan pembelajaran al-Qur'an diikuti oleh seluruh pengajar. Adanya pengelompokan santri dalam kelas-kelas tertentu sesuai dengan tingkat kemampuan. Kedua, adanya pengorganisasian yang jelas, sehingga membantu setiap komponen dapat bekerja sesuai wewenang dan tanggung jawab dalam pembelajaran al-Qur'an. Ketiga, dalam pelaksanaan pembelajaran al-Qur'an terdapat perlakuan yang berbeda pada masing-masing kelas, sehingga dapat memaksimalkan kemampuan santri. Keempat, evaluasi pembelajaran al-Qur'an dilakukan secara menyeluruh, tidak hanya melihat pada hasil belajar akan tetapi juga proses pembelajaran berlangsung. Implikasi penelitian ini adalah pada pengembangan "teori managemen pembalajaran al-Qur'an" dalam khazanah pendidikan Islam.

Kata Kunci: Manajemen, Manajemen Pembelajaran, Pembelajaran Al Qur'an, Pesantren

Jurnal Pendidikan Agama Islam Al-Thariqah Vol. 6, No. 1, Januari - Juni 2021

Received : 29 Mei 2021; Accepted : 21 Juni 2021; Published : 30 Juni 2021

*Corresponding Author : rosyidaistiqomah99@gmail.com 


\section{PENDAHULUAN}

Pembelajaran al-Qur'an sangat urgen dimiliki oleh setiap lembaga pendidikan Islam, sebab menjadi kunci sukses dalam kemajuan membangun generasi Islami di masa yang akan datang. Pencapaian pendidikan nasional yang diraih Indonesia dalam kaitannya dengan persaingan pendidikan secara global mesti diawali dengan pengembangan pembelajaran ilmu dasar yaitu al-Qur'an. Hasil dari pendidikan yang konservatif mengakibatkan sumber daya manusia yang dihasilkan dari lembaga pendidikan Indonesia masih memerlukan perbaikan untuk keunggulan kualitas dan lainnya bersama dengan negara lain di dunia. Menghadapi hal tersebut, dibutuhkan berbagai upaya yang kreatif dan inovatif agar kualitas pendidikan Indonesia di masa yang akan datang bisa berdampingan dan sejajar dengan negaranegara maju lainnya (Efferi, 2015; Ahmad, Tambak, and Hasanah, 2018; Nasional, 2006).

Dalam memecahkan masalahmasalah pendidikan, maka perlu diperhatikan beberapa aspek eksternal dan internal. Aspek eksternal diantaranya aspek politik, ekonomi, sosial-budaya, pertahanan dan keamanan bahkan ideologi. Sedangkan faktor internal yaitu guru, peserta didik, kurikulum, manajemen, metode dan lingkungan. Oleh karena itu, manajemen pembelajaran merupakan suatu faktor penting dalam menentukan keberhasilan proses pendidikan (Hamzah, et al, 2020). Maka sangat diperlukan perhatian yang besar terhadap manajemen pembelajaran yang dapat meningkatkan kualitas pendidikan.

Belajar merupakan suatu proses perubahan tingkah laku seseorang yang merupakan hasil dari sebuah pengalaman (Tambak, et al 2018). Proses belajar bersifat internal, setiap individu memiliki cara yang unik dalam belajar. Sedangkan pembelajaran merupakan sebuah pengondisian lingkungan agar proses belajar dapat berjalan secara optimal.
Pembelajaran ini bersifat eksternal yang sengaja dirancang dengan berbagai tujuan tertentu (Skinner, 2013; Ahmad, and Tambak, 2018). Pembelajaran adalah sebuah rangkaian kegiatan yang telah direncanakan oleh para guru untuk dapat diterapkan pada proses transfer ilmu kepada siswanya. Pembelajaran sebagai suatu kegiatan yang dirancang oleh guru yang menekankan pada peranan peserta didik sebagai subjek belajar (Noer, Tambak, and Rahman, 2017).

Terdapat dua hal yang mempengaruhi keberhasilan pembelajaran yaitu faktor dari dalam diri individu yang sedang belajar serta faktor dari luar individu. Faktor dari dalam diri individu dipengaruhi oleh sifat genetik yaitu psikis dan fisik. Sedangkan lingkungan alam, sosial-ekonomi, kurikulum, guru, metode serta sarana prasarana termasuk faktor dari luar individu dipengaruhi oleh hal-hal yang berkaitan dengan suasana sosial (Rukajat, 2018; Tambak, Ahmad, and Sukenti, 2020; Nasional, 2006).

Pembelajaran merupakan suatu sistem, sehingga dalam pengelolaan pembelajaran dibutuhkan perencanaan yang tepat. Pengelolaan pembelajaran biasa disebut dengan manajemen pembelajaran. Manajemen pembelajaran adalah proses pengelolaan pembelajaran, berawal dari perencanaan, pengorganisasian, pelaksanaan dan evaluasi. Ini merupakan pengertian manajemen pembelajaran dalam arti luas. Sedangkan dalam arti sempit berarti, pengelolaan yang dilakukan oleh para guru selama proses interaksi dengan siswa dalam pelaksanaan pembelajaran (Rukajat, 2018; Tambak, 2010).

Dalam manajemen pembelajaran yang merupakan suatu sistem, terdiri dari beberapa komponen yang saling terkait. Hubungan antar komponen itu sangatlah erat kaitannya dengan keberhasilan pembelajaran. Komponen-komponen tersebut terdiri atas tujuan pembelajaran, bahan ajar, media, strategi dan evaluasi 
pembelajaran. Dalam setiap komponen tersebut terdapat manajemen dalam pengoprasiannya, yaitu perencanaan, pengorganisasian, pelaksanaan dan evaluasi.

Pesantren merupakan sebuah lembaga pendidikan Islam yang tumbuh bersamaan dengan proses islamisasi nusantara sekitar tujuh abad yang lalu. Pesantren termasuk salah satu lembaga pendidikan Islam tertua di Indonesia yang kehadirannya bersifat tradisional (Syafe'i, 2017; Tambak, 2014). Kehadiran pondok pesantren membawa beberapa peran dakwah Islamiyah dengan tujuan untuk mencetak kader ulama yang ahli agama, memiliki kecerdasan pengetahuan, dan mampu berdiri sendiri (Hakim and Herlina, 2018). Acuan pembelajaran pesantren berbeda dengan dengan sekolah formal. Acuan pembelajaran pesantren dirancang oleh pihak pondok sehingga bersifat lebih dinamis dibandingkan dengan sekolah formal. Bahan ajar yang digunakan dalam pembelajaran di pesantren bersumber dari Al-Qur'an dan hadits serta kitab-kitab kuning (Inayati et al., 2020)

Dalam proses pembelajaran di pondok pesantren, ilmu-ilmu keislaman menjadi sebuah prioritas utama (Siregar, 2018). Berbeda dengan lembaga pendidikan lainnya, pondok pesantren memiliki lima unsur atau komponen. Lima komponen itu adalah Kiyai, santri, asrama, masjid, dan pengajian kitab (Romdoni, and Malihah, 2020). Hal penting di pesantren juga termasuk pembelajaran alQur'an. Pembelajaran di pondok pesantren tidak akan terlepas dari pembelajaran Al-Quran, karena merupakan program utama yang menjadi dasar bagi seorang muslim. Pembelajaran Al-Qur'an adalah sebuah interaksi antara pendidik dan murid untuk mempelajari sebuah kitab suci agama Islam yang berisikan firman-firman Allah SWT yang memiliki sifat Maha Agung (Afandi, 2020; Tambak, 2019). Pada umumnya pembelajaran Al-Qur'an di pondok pesantren diajarkan secara talaqqi, yakni langsung dari guru kepada muridnya.

Beberapa pemerhati pendidikan telah melakukan penelitian mengenai manajemen pembelajaran. Penelitianpenelitian terdahulu yang memiliki relefansi dengan penelitian ini diantaranya adalah penelitian mengenai manajemen pembelajaran tahfidz AlQur'an. Tujuan dari penelitian tersebut adalah mendeskripsikan pengelolaan pembelajaran tahfidz Al-Qur'an. Penelitian yang dilakukan oleh Fatmawati (2019) ini memiliki kesamaan dalam hal manajemen pembelajaran. Perbedaanya terletak pada fokus dari objek penelitian, yaitu manajemen pembelajaran tahfidz dan manajemen pembelajaran Al-Quran.

Penelitian lain dilakukan oleh Suryapermana (2016) yang meneliti tentang manajemen pembelajaran dalam dunia pendidikan. Penelitian ini mengeksplor cara-cara terciptanya proses pembelajaran yang baik. Guru merancang dan meracik materi pelajaran secara detail sehingga tercipta rasa senang dari dalam diri siswa. Penelitian ini lebih umum dibandingkan dengan penelitian yang dilakukan oleh peneliti. Penelitian selanjutnya dilakukan oleh Inayati, and Safina (2019) mengenai manajemen pembelajaran sekolah dasar di daerah tertinggal. Penelitian ini bertujuan untuk mendeskripsikan proses penyusunan program, implementasi, evaluasi, serta mengidentifikasi faktor penghambat dan pendukung dilengkapi dengan solusi dari faktor penghambat. Manajemen pembelajaran yang dikaji dalam penelitian ini bersifat umum yakni keseluruhan pembelajaran yang ada di sekolah dasar, sedangkan penelitian yang ditulis ini adalah penelitian manajemen pembelajaran Al-Quran di pondok pesantren.

Pondok pesantren Bahrul Ulum, adalah salah satu pondok pesantren yang memiliki perhatian besar terhadap AlQuran. Pondok pesantren ini terletak di Desa Tangsil Kulon, Bondowoso. Visi pondok pesantren Bahrul Ulum adalah 
unggul dalam prestasi, kompetitif, mandiri, dan berjiwa Qurani. Visi besar tersebut di realisasikan melalui beberapa misi yaitu, melahirkan generasi penerus yang berkeimanan dan kualitas berkemampuan, memotivasi santri untuk gemar mengaji dan mengkaji islam, mewujudkan dalam pengembangan keislaman, meningkatkan sumber daya pendidik dan kependidikan yang professional, mewujudkan pembelajaran yang berbasis keagamaan secara efektif mewujudkan lingkungan pendidikan yang kreatif, edukatif, religious dan akuntabel, mengembangkan seni budaya yang relevan dengan ciri khas kabupaten Langkat menuju kebudayaan lokal, nasional dan internasional.

Pondok pesantren ini terletak disuatu desa yang masyarakatnya sangat menjunjung tinggi agama, akan tetapi dalam hal al-Qur'an, mereka sekedar dapat membaca dengan benar tanpa adanya minat untuk mempelajarinya lebih dalam. Merujuk pada visi pondok yaitu unggul dan berjiwa Al-Qur'an, maka pembelajaran Al-Qur'an di pondok pesantren ini sangatlah diperhatikan. Secara umum, ilmu-ilmu Al-Qur'an yang di ajarkan di pondok pesantren ini mulai dari yang paling dasar yaitu pengenalan huruf hijaiyah hingga tahfidz dan tafsir. Pengajar berharap agar para santri yang menghafal Al-Qur'an tidak hanya hafal ayat-ayatnya akan tetapi juga memahami kandungannya. Pondok pesantren dengan sistem pendidikan Islam tradisional ini, ingin turut berperan dalam mencetak sumber daya manusia yang unggul dalam bidang Al-Qur'an, serta pemelihara tradisi islam (Siregar, 2018; Tambak, Ahmad, and Sukenti, 2020).

Tujuan serta harapan pondok pesantren tersebut dapat terwujud dengan adanya manajemen yang baik. Perlu terjalin hubungan harmonis antara pihak pondok pesantren dengan masyarakat sekitar. Adanya campur tangan masyarakat merupakan indikator adanya kepedulian rasa kepemilikan.
Kerjasama antara pihak pondok pesantren, siswa, orang tua, serta penilaian yang seimbang dari stakeholder sangat berpengaruh pada pencapaian tujuan (Arisanti, 2016).

Fokus penelitian ini adalah; (1) Manajemen perencanaan kegiatan pembelajaran al-Qur'an di Pondok Pesantren Bahrul Ulum Bondowoso Jawa Timur; (2) Manajemen pengorganisasian kegiatan pembelajaran al-Qur'an di Pondok Pesantren Bahrul Ulum Bondowoso Jawa Timur; (3) Manajemen pelaksanaan kegiatan pembelajaran alQur'an di Pondok Pesantren Bahrul Ulum Bondowoso Jawa Timur; dan (4) Manajemen evaluasi kegiatan pembelajaran al-Qur'an di Pondok Pesantren Bahrul Ulum Bondowoso Jawa Timur.

\section{KONSEP TEORI}

Manajemen merupakan kekuatan utama dalam sebuah organisasi. Manajemen merupakan proses memperoleh tindakan melalui orang lain. Manajemen adalah suatu proses memadukan sumber daya yang ada ke dalam keseluruhan sistem demi tercapainya tujuan. Manajemen pembelajaran merupakan proses pemberdayaan sumber daya dalam sebuah kegiatan pembelajaran dalam mencapai tujuan (Syafaruddin, 2005). Dalam manajemen pembelajaran setidaknya terdiri dari empat langkah yaitu perencanaan, pengorganisasian, pelaksanaan dan evaluasi. Keempat langkah tersebut akan diulas dalam penelitian ini secara praktikal melalui data-data lapangan yang telah dikumpulkan peneliti (Widayati, 2018).

Pertama, perencanaan. Perencanaan merupakan suatu kegiatan merancang tujuan serta menentukan cara dalam mencapai tujuan tersebut (Syafaruddin, 2005). Dalam manajemen pembelajaran penting untuk menentukan arah tujuan pembelajaran. Pada umumnya dalam 
pembelajaran perencaan ini dapat berupa kegiatan perancangan RPP.

Kedua, pengorganisasian atau organize berarti mengintegrasikan subsub sehingga terciptanya hubungan antara satu dengan lainnya. Lebih mudahnya, organisasi menghasilkan garis integrasi berupa skema yang menunjukkan kedudukan serta hubungan antara Stu dengan lainnya (Rahmawati, 2018) kegiatan pengadaan integrasi ini dapat dilakukan dengan langkah-langkah berikut ini: (1) manajer mengetahui tujuan organisasi. Tentu suatu kelompok kerja memiliki satu tujuan yang sama, dan tujuan inilah yang menetukan arah jalanjalan apa saja yang akan ditempuh demi tercapainya tujuan tersebut; menentukan kegiatan organisasi. Kegiatan-kegiatan yang ditentukan berdasarkan tujuan adalah upaya agar tujuan dapat terealisir dengan baik; (3) mengelompokkan kegiatan organisasi; (4) menugaskan hak atau wewenang kepada setiap anggota. Adanya pembagian tugas yang jelas dapat mempermudah setiap anggota untuk turut mensukseskan kegiatan-kegiatan yang telah dirancang; (5) rentang kendali; (6) peranan individu. Setiap individu dapat melakukan tugas masing-masing serta membantu individu lain saat tugasnya telah selesai; (7) tipe organisasi. Ada beberapa macam tipe organisasi, dalam pembentukan struktur hendaknya menyesuaikan tipe yang sesuai dan selaras dengan tujuan, hal ini akam mempermudah pada langkah-langkah lain; (8) adanya struktur organisasi yang jelas (Saefrudin, 2017).

Ketiga, pelaksanaan. Pelaksanaan berati melaksanaan rancangan yang telah disepakati pada langkah perencanaan (Suhendri, 2017). Terkadang pada proses pelaksanaan tidak sesuai dengan apa yang telah direncanakan. Situasi dan kondisi yang tidak sesuai prediksi dapat menjadi faktor utama dalam pelaksanaan kegiatan yang telah direncanakan. Maka, disinilah fungsi evaluasi bekerja.

Keempat, evaluasi pembelajaran. Evaluasi merupakan kegiatan membandingkan antara pelaksanaan dengan rencana yang telah disusun pada kegiatan perencanaan, kemudian mengidentifikasi hambatan-hambatan serta faktor pendukung. Hasil dari kegiatan evaluasi ini akan menjadi pertimbangan pada kegiatan perencanaan, pengorganisasian serat pelaksanaan selanjutnya (Suhendri, 2017). Evaluasi adalah salah satu alat untuk mengetahui hasil kemajuan belajar peserta didik yang harus dilakukan dengan baik. (Rahayu, 2015).

Al Qur'an merupakan suatu kitab suci umat Islam yang diharapkan mampu membimbing dan merupakan pedoman dalam mengarungi bahtera kehidupan. Di dalam al Qur'an terkandung nilai dan konsep pemecahan masalah yang dihadapi manusia, baik masalah keagamaan maupun masalah social kemasyarakatan. Namun pada kenyataannya masih banyak di antara umat Islam yang belum dapat membaca $\mathrm{Al}$ Qur'an dengan baik dan benar. (Nisak, 2018).

Pembelajaran Al-Qur'an memiliki sebuah tujuan yaitu: 1 . Agar pelajar dapat membaca dengan fashih dan benar menurut tajwid, 2. Agar pelajar dapat membiasakan Al-Qur'an dalam kehidupannya, dan 3. Memperkaya pembendaharaan kata-kata dan kalimatkalimat indah dan menarik hati. Dalam pembelajaran Al-Qur'an hal-hal berikut yang perlu diajarkan; 1 . Pengenalan huruf hijaiyah, 2. Cara membunyikan hurufhuruf hijaiyah dan sifat-sifat huruf, 3 . Bentuk dan fungsi tanda baca, 4. Bentuk dan fungsi tanda berhenti baca (waqaf), 5 . Cara membaca, melagukan dengan bermacam-macam irama dan qiraat, dan 6. Adabut tilawah (Ma'mun, 2018).

\section{METODE PENELITIAN}

Jenis penelitian yang digunakan dalam kajian ini adalah penelitian kualitatif dengan pendekatan studi kasus untuk menganalisis manajemen pembelajaran Al-Qur'an di Pondok Pesantren Bahrul Ulum Bondowoso. 
Penelitian ini dilaksanakan pada periode semester genap tahun 2019-2020 yang berlokasi di Pondok Pesantren Bahrul Ulum Tangsil Kulon Bondowoso Provinsi Jawa Timur Indonesia.

Informan penelitian ini terdiri dari 7 informan, yaitu: Dr. KH. Zarkasyi, M.Pd (1). berusia 51 tahun yang merupakan pengasuh pondok pesantren dari awal berdiri sampai sekarang. Kholilatul Izzah (2) berusia 28 tahun, mengajar Al Qur'an selama 5 tahun. Haliyah (3) berusia 18 tahun, mengajar selama 2 tahun. Maghfiroh (4) yang berusia 15 tahun, mengajar selama setahun. Nuraini (5), Sudarsih (6), dan Maulid (7) yang merupakan santri pondok pesantren Bahrul Ulum dengan kelas Al-Qur'an yang berbeda-beda. Ketujuh informan tersebut menetap di pondok pesantren Bahrul Ulum.

Adapun teknik pengumpulan data yang digunakan meliputi observasi dan wawancara kepada informan penelitian. Peneliti menggunakan observasi tidak struktur yaitu observasi yang tidak dipersiapkan secara sistematis tentang apa yang akan diamati (Sugiyono, 2015). Hal ini agar peneliti dapat mengembangkan daya pengamatannya dalam mengamati objek. Dalam hal wawancara, peneliti berinteraksi langsung dengan informan wawancara yang dilakukan terhadap pengasuh dan pengajar Pondok Pesantren Bahrul Ulum Tangsil Kulon Bondowoso untuk memperoleh data yang berkaitan dengan manajemen pembelajaran al-Qur'an. Adapun teknik analisis data, peneliti menggunakan teori yang dikemukakan oleh Miles dan Huberman bahwa proses analisis data terbagi menjadi tiga tahapan yaitu reduksi data, penyajian data, dan penarikan kesimpulan dan verifikasi data (Sugiyono, 2015). Peneliti mereduksi data dengan merangkum data yang diperoleh dan memilih data-data pokok yang diperlukan. Sehingga memperoleh data yang lebih jelas dan memudahkan untuk memperoleh data-data selanjutnya.
Kemudian peneliti menyajikan data-data yang telah diperoleh, menggabungkan data data yang telah disusun sehingga memungkinkan untuk ditarik kesimpulan dan memverifikasinya.

\section{HASIL DAN PEMBAHASAN \\ Perencanaan Pembelajaran Al-Qur'an}

Pondok Pesantren Bahrul Ulum merupakan salah satu pesantren yang terletak di desa Tangsil Kulon Kecamatan Tenggarang Kabupaten Bondowoso. Pesantren ini merupakan suatu pesantren yang mempelajari berbagai macam ilmu agama dan umum. Salah satu yang diterapkan dan dijaga kelestariannya adalah ilmu al-Qur'an.

"Perencanaan pembelajaran alQur'an di Pondok Pesantren Bahrul Ulum Tangsil Kulon Bondowoso ini bermula dari diadakannya suatu rapat antara pengasuh serta beberapa pengajar pesantren" (1). Dalam rapat tersebut, "membahas suatu tujuan pembelajaran secara keseluruhan terutama dalam pembelajaran al-Qur'an. Serta penentuan pengajar yang bertanggung jawab penuh atas terlaksananya suatu proses pembelajaran al-Qur'an" (2). "Pengajar yang bertanggung jawab dalam al-Qur'an dibebaskan merancang perencanaan pembelajaran yang tentunya tidak terlepas dari kurikulum pembelajaran yang telah disiapkan oleh pondok pesantren" (3). Perencanaan pembelajaran merupakan suatu proses awal dalam merancang segala sesuatu yang menjadi acuan pengajar sebelum dilaksanakannya suatu pembelajaran di kelas (Ahmad, 2020).

Dalam perencanaan pembelajaran al-Qur'an, "pengajar menentukan kelas berdasarkan hasil dari seleksi kemampuan santri dalam membaca alQur'an yang dibagi menjadi 3 kelas yaitu Alfashlul Awwal untuk kelas tertinggi, santri dalam kelas ini sedikit banyak telah menguasai makhorijul huruf, fashohatul kalam dan tajwid. Alfashluts tsani merupakan kelas bagi santri yang baru 
mengenal makhorijul huruf, fashohatul kalam dan tajwid. Untuk kelas terakhir yaitu Alfashluts tsalits merupakan kelas bagi santri yang belum mengenal makhorijul huruf, fashohatul kalam serta tajwid" (1). "Setelah pembagian kelas tersebut, santri boleh memasuki kelas masing-masing menurut kemampuan mereka yang telah ditetapkan oleh pengajar al-Qur'an" (4).

Adapun mengenai langkah-langkah perencanaan pembelajaran yang meliputi: tujuan pembelajaran, materi pembelajaran, metode dan media pembelajaran, dan alokasi waktu pembelajaran (Inayati and Safina, 2019; Tambak, 2014) Pertama, "Pondok Pesantren Bahrul Ulum ini memiliki suatu target utama yang harus dicapai dalam pembelajaran al-Qur'an, yaitu agar santri dapat membaca Al-Qur'an dengan fasih dan lancar sesuai dengan qoidah tajwid" (1). Kedua, "materi yang diajarkan antar kelas tidaklah sama, tergantung dari kemampuan masing-masing santri dalam kelas tersebut. Seperti halnya alfashlul awwal yang telah memahami makhorijul huruf, fashohatul kalam dan tajwid. Dalam kelas ini tidaklah materi yang diajarkan seperti kelas lainnya, tetapi lebih kedalam penerapannya dalam al-Qur'an, serta menghafal al-Qur'an dan tafsirnya. Beda halnya dengan alfashluts tsani yang baru memahami makhorijul huruf, fashohatul kalam dan tajwid, sehingga materi yang diajarkan yaitu seluruh materi mengenai makhorijul huruf, fashohatul kalam dan tajwid serta penerapannya dalam membaca Al-Qur'an. Namun dengan alfashluts tsalits, materi yang diajarkan sangatlah berbeda, dikarenakan santri dalam kelas ini baru akan memulai untuk mempelajari ilmu makhorijul huruf, fashohatul kalam dan tajwid" (2). Ketiga, "metode pembelajaran Al-Qur'an di pesantren ini yaitu metode qiroati dengan menggunakan kitab Miftahul Huda fii Ma'rifatil Waqfi wal Ibtida'. Dalam kitab ini membahas tentang makhorijul huruf, tajwid dan lain-lain" (2). Keempat, "pelaksanaan pembelajaran Al-Qur'an di pesantren ini berbeda-beda. Materi untuk alfashlul awwal dilaksanakan setiap malam sabtu setelah sholat maghrib. Sedangkan untuk alfashluts tsani dilaksanakan setiap malam sabtu setelah sholat isya' berjama'ah. Dan untuk alfashluts tsalits dilaksanakan keesokan harinya pada malam minggu setelah sholat maghrib, pada kelas ini pengajar membutuhkan waktu yang cukup lama dikarenakan santri pada kelas ini masih benar-benar belum memahami dan mengenal ilmu makhorijul huruf, fashohatul kalam dan tajwid" (1).

Dengan hal ini, "Pondok Pesantren Bahrul Ulum sangat menekankan pengajar agar memiliki sebuah rencana untuk santri selama setahun kedepan. Salah satunya dengan memberikan berbagai materi yang diajarkan sesuai kemampuan mengaji al-Quran mereka di kelas masingmasing. Sehingga terbentuklah rasa daya saing santri di dalam kelas tanpa ada santi yang merasa tertinggal. Oleh karena itu, peneliti mengambil kesimpulan bahwa perencanaan pembelajaran merupakan suatu proses awal dalam merancang segala sesuatu yang menjadi acuan sebelum pelaksanaan pembelajaran dilakukan" (3).

Temuan penelitian ini sejalan dengan hasil penelitian terdahulu yang dilakukan oleh Ahmad (2020) bahwa rencana program dibuat dengan tujuan untuk memperjelas bagaimana suatu visi dapat dicapai. Begitu juga dengan ungkapan Fatmawati (2019) bahwa perencanaan memiliki peran utama yang sangat penting diantara fungsi-fungsi manajemen lainnya. Perencanaan dalam managemen berdampak luas bagi pengembangan sebuah lembaga pendidikan dan juga pada proses pembelajaran yang berkualitas dan unggul pada peserta didik.

\section{Pengorganisasian Pembelajaran Al- Qur'an}

Pengorganisasian merupakan suatu upaya dalam mengelompokkan beberapa rencana yang telah dibuat dan disusun 
oleh suatu lembaga organisasi. Pengorganisasian pembelajaran yaitu pengelompokkan beberapa komponen pembelajaran ke dalam susunan lembaga yang teratur, membuat struktur wewenang tanggung jawab dan mekanisme koordinasi pembelajaran, penyediaan fasilitas (Inayati and Safina, 2019; Tambak, 2010).

Adapun temuan penelitian mengenai pengorganisasian pembelajaran di Pondok Pesantren Bahrul Ulum Tangsil Kulon Bondowoso adalah: "pengasuh pesantren membentuk suatu struktur wewenang tanggung jawab kepada pengajar agar dibentuk suatu kepengurusan dalam pembelajaran al-Qur'an. Membentuk koordinasi pada masing-masing kelas dan mengelompokkan santri berdasarkan kemampuan masing-masing. Sedangkan fasilitas yang disediakan untuk pembelajaran al-Qur'an hanya dalam satu tempat namun dalam waktu yang berbeda-beda" (1). "Penanggung jawab pembelajaran al-Qur'an membagi pengajar khusus materi dan prakteknya. Materi pembelajaran al-Qur'an dipandu oleh satu orang pengajar, sedangkan untuk prakteknya dipandu oleh tiga orang pengajar disetiap malamnya setelah sholat maghrib" (2).

Hal ini sesuai dengan pengorganisasian pembelajaran yang terdapat di pondok pesantren Bahrul Ulum bahwa "pengorganisasian benarbenar disempurnakan dalam hal pembagian tugas mengajar dan materi yang disesuaikan dengan kemampuan santri. Sehingga pengorganisasian yang terjadi di pesantren ini sangatlah terorganisasi dengan baik" (4). Hasil dari temuan yang telah ditemukan, diperkuat penelitian terdahulu bahwa pengorganisasian merupakan sebuah wadah atau bentuk perserikatan kerja sama sesama manusia (Istiqomah et al. 2020). Pengorganisasian dilakukan untuk menentukan tata cara kegiatan yang akan berlangsung (Ahmad, 2020; alMunawwar, Tambak, and Kalsum, 2003).

\section{Pelaksanaan Pembelajaran Al-Qur'an}

Pelaksanaan pembelajaran yaitu mengerjakan rancangan dari apa yang telah dibuat dan direncanakan dalam suatu program (Fatmawati, 2019). Pelaksanaan pembelajaran mencakup tiga kegiatan yaitu pendahuluan, inti dan penutup (Gunawan and Benty). Tugas seorang pengajar dalam pembelajaran adalah sebagai seorang manajer yang memiliki kemampuan untuk memimpin, mempengaruhi, membimbing, mengarahkan, memotivasi santri agar melaksanakan pekerjaan sebaik mungkin. Oleh karena itu, komunikasi antara pengajar dan santri menjadi faktor terpenting dalam suatu proses pembelajaran.

Hal ini sesuai dengan data yang ditemukan "pada proses pembelajaran alQur'an di Pondok Pesantren Bahrul Ulum Tangsil Kulon Bondowoso yang dilakukan setiap malam setelah maghrib dan setelah isya'. Pada malam sabtu dan minggu, beberapa materi yang diajarkan dikelas adalah makhorijul huruf, fashohatul kalam atau tajwid. Sedangkan pada malammalam lainnya, lebih difokuskan untuk penerapan dari materi-materi yang telah diajarkan sebelumnya. Pada proses pembelajaran al-Qur'an di kelas, diawali dengan pendahuluan yang mana pengajar membuka pelajaran dengan salam dan mengabsen santri. Kemudian pada kegiatan inti, setiap kelas berbeda-beda" (4).

"Pada alfashlul awwal yang merupakan kelas tertinggi di pesantren ini, santri lebih difokuskan pada hafalan al-Qur'an dan tafsirnya. Namun, khusus untuk kelas ini, ada kelas khusus yang dilaksanakan pada malam kamis setelah maghrib dan malam minggu setelah isya'. Pada malam tersebut, santri alfashlul awwal mengulang hafalan al-Qur'an mereka secara bersama-sama dengan suara yang lantang dan saling memperbaiki bacaan-bacaan mereka yang masih kurang. Selain pada kedua malam tersebut, mereka mengulang atau 
menambah hafalan atas kemampuan mereka dan disetorkan ke pengajar setiap Senin pagi setelah shalat shubuh. Sedangkan pada malam Sabtu setelah maghrib, santri secara bergantian menjabarkan materi-materi yang telah mereka kuasai serta dijelaskan menurut pemahaman mereka ke pengajar di depan teman-teman lainnya" (1).

"Pada alfashluts tsani, lebih difokuskan kepada pengayaan materi seperti makhorijul huruf, fashohatul kalam dan tajwid yang dilaksanakan pada malam sabtu setelah isya"' (1). "Pada kegiatan ini, mereka dijabarkan suatu materi oleh pengajar serta prakteknya secara bergantian dalam membaca al-Qur'an. Selain hari itu, mereka hanya membaca alQur'an kepada pengajar al-Qur'an lainnya dengan bacaan yang benar sesuai dengan materi yang telah mereka pelajari pada malam sabtu sebelumnya" (2).

"Pada alfashluts tsalits yang merupakan kelas bagi santri yang belum bisa membaca al-Qur'an ini dilaksanakan pada malam minggu setelah maghrib. Pada kegiatan ini, pengajar benar-benar mengarahkan dan menjelaskan tentang perbedaan huruf, fashohatul kalam, dll. Karena di kelas ini, santri belum benarbenar faham al-Qur'an. Oleh karenanya, pengajar di kelas ini berupaya keras untuk keberhasilan santri dalam mengajarkan materi. Selain malam minggu, santri mengaji al-Qur'an ke pengajar lainnya dengan memperhatikan makroj, tajwid, dan lain-lain" (1).

Setelah kegiatan inti berlangsung, "pengajar menutup pembelajaran ini dengan memberikan motivasi kepada santri dan menutupnya dengan salam. Kegiatan ini berlangsung sekitar 30-45 menit setiap kali pertemuan. Kecuali pada kelas alfashlul awwal ketika hari senin pagi, karena pada saat itu santri menyetorkan hafalannya masing-masing dan membutuhkan waktu yang lama" (4).

Pelaksanaan pembelajaran al-Qur'an di sebuah lembaga pendidikan sangat urgen dilakukan untuk membentuk akhlak peserta didik. "Pembelajaran al-Qur'an dapat membantu peserta didik meningkatkan akhlak dalam kehidupan sehari-hari. Pelaksanaan pembelajaran alQur'an sangat baik dilaksanakan di pesantren, dan kami merasa senang untuk mengikutinya dalam kehidupan pembelajaran" (6). Hal ini sangat penting dalam mengembangkan akhlak peserta didik, di mana pembelajaran al-Qur'an dapat mengembangkan sikap lemah lembut, ketakwaan, dan lebih disiplin dalam kehidupan sehari-hari (Tambak, et al. 2021).

\section{Evaluasi Pembelajaran Al-Qur'an}

Evaluasi merupakan suatu kegiatan untuk mengetahui tingkat keberhasilan suatu program. Sehingga akan diketahui indikator yang menyebabkan sukses atau tidaknya pencapaian suatu tujuan. Evaluasi berfungsi untuk meneliti dan mengetahui pelaksanaan pembelajaran yang telah dilakukan dalam proses mencapai tujuan pembelajaran (Ahmad, 2020).

Evaluasi pembelajaran al-Qur'an di Pondok Pesantren Bahrul Ulum Tangsil Kulon Tenggarang ini "dilakukan melalui dua cara, yaitu melalui penilaian proses pembelajaran dan penilaian hasil pembelajaran. Pertama, penilaian proses pembelajaran ini dilakukan dengan mengamati siswa dalam proses pembelajaran, baik di alfashlul awwal, alfashluts tsani, atau alfashluts tsalits. Dalam hal ini, pengajar mengamati keaktifan siswa, kesiapan dalam menerima materi pembelajaran, dan ketekunan siswa. Pada penilaian ini, pengajar langsung menilai siswa saat proses pembelajaran berlangsung" (2).

Kedua, "penilaian hasil pembelajaran. Dalam penilaian ini Pondok Pesantren Bahrul Ulum Tangsil Kulon Bondowoso ini, terdapat dua macam penilaian yaitu penilaian materi dan praktek. Pengajar mengevaluasi setiap kelas berbeda-beda. Seperti penilaian materi di alfashlul awwal dengan evaluasi tambahan hafalan al-Qur'an mereka dan tafsirnya setiap senin pagi, dalam kelas ini 
ada buku penilaian khusus untuk setiap siswa. Untuk alfashluts tsani dan alfashluts tsalits, penilaian materi dilaksanakan secara bergantian setiap dua minggu sekali. Namun, berbeda lagi pada evaluasi prakteknya yang dilaksanakan setiap tiga minggu sekali secara bergantian dimulai dari alfashlul awwal, alfashluts tsani, dan alfashluts tsalits" (2).

Berdasarkan hal tersebut di atas, tergambar bahwa tahap evaluasi merupakan tahapan yang sangat penting dalam manajemen pembelajaran, karena berhasil tidaknya pengajar dalam melaksanakan proses pembelajaran dapat diukur dari tahap evaluasi pembelajaran. "Selama ini yang dilakukan pengajar alQur'an di Pondok Pesantren Bahrul Ulum Tangsil Kulon Bondowoso ini sudah sangat baik mengukur sejauh mana keberhasilan pengajar dalam pembelajarannya" (7).

Temuan penelitian menguatkan hasil penelitian Sukenti, Tambak, and Charlina (2020) bahwa evaluasi harus dijalankan dalam setiap kegiatan pembelajaran di sekolah. Di samping mengukur hasil belajar peserta didik, juga mengukur berbagai kegiatan yang dilakukan oleh para pengajar, juga mesti melakukan tindak lanjut dalam perbaikan dan kemajuan pendidikan. Evaluasi yang dilakukan dengan berkesinambungan akan berdampak pada mutu sekolah, pembelajaran, dan peserta didik dalam kegiatan proses pembelajaran dan profesionalisme guru pun akan meningkat dari masa ke masa (Tambak and Sukenti, 2020).

\section{PENUTUP}

Berdasarkan pemaparan data di atas, dapat ditegaskan hasil penelitian bahwasanya pondok pesantren Bahrul Ulum Tangsil Kulon Bondowoso memiliki manajemen pembelajaran al-Qur'an yang sistematis. Pertama, kegiatan perencanaan pembelajaran al-Qur'an diikuti oleh seluruh pengajar. Adanya pengelompokan santri dalam kelas-kelas tertentu sesuai dengan tingkat kemampuan dapat mempermudah menuju keberhasilan pembelajaran. Kedua, adanya pengorganisasian yang jelas, sehingga membantu setiap komponen dapat bekerja sesuai wewenang dan tanggung jawab dalam pembelajaran al-Qur'an. Ketiga, dalam pelaksanaan pembelajaran al-Qur'an terdapat perlakuan yang berbeda pada masing-masing kelas, sehingga dapat memaksimalkan kemampuan santri. Keempat, evaluasi pembelajaran al-Qur'an dilakukan secara menyeluruh, tidak hanya melihat pada hasil belajar akan tetapi juga proses pembelajaran berlangsung. Selain itu, evaluasi hasil pembelajaran al-Qur'an tidak hanya penilaian teori akan tetapi praktik yang dilakukan setiap tiga minggu sekali. Implikasi penelitian ini adalah pada pengembangan "teori managemen pembalajaran al-Qur'an" dalam khazanah pendidikan Islam.

\section{DAFTAR RUJUKAN}

Afandi, Irfan. "Pembelajaran Al-Qur'an Anti Radikalisme Di Kalangan Pelajar Sekolah Menengah." Tarbiyatuna 4. 1 (2020): 34-47. doi:https://doi.org/10.29062/tarbiy atuna.v4i1.296.

Ahmad, Aris. "Manajemen Pembelajaran Pendidikan Agama Islam Dalam Pembentukan Karakter Siswa Di SMA Primaganda Jombang." Turatsuna 22 (2020): 1-14.

Ahmad, Muhammad Yusuf, Syahraini Tambak, and Uswatun Hasanah. "Pengaruh Kecerdasan Emosional terhadap Penyesuaian Diri Mahasiswa Thailand." Al-Hikmah: Jurnal Agama dan Ilmu Pengetahuan 15.2 (2018): 16-30. https://doi.org/10.25299/alhikmah:jaip.2018.vol15(2).2374.

Ahmad, Muhammad Yusuf, and Syahraini Tambak. "Penanaman Nilai-Nilai Pendidikan Akidah Melalui Mata Pelajaran Sejarah Kebudayaan Islam (SKI)." Al-Hikmah: Jurnal Agama dan 
Ilmu Pengetahuan 15.1 (2018): 2441.

https://doi.org/10.25299/jaip.2018. vol15(1).1581.

Ahmad, Muhammad Yusuf, Syahraini Tambak, and Mira Syafitri. "Etika Pergaulan Islami Santri Madrasah Aliyah (MA) di Pesantren Jabal Nur Kecamatan Kandis Kabupaten Siak." Al-Hikmah: Jurnal Agama dan Ilmu Pengetahuan 13.2 (2016): 206-226. https://doi.org/10.25299/alhikmah:jaip.2016.vol13(2).1524.

Ahmad, Mawardi. "Hubungan Potensi Akal dengan Kreativitas Belajar Siswa Bidang Studi Pendidikan Agama Islam di SMK Kanada Sakura Indonesia (KANSAI) Pekanbaru." Jurnal Pendidikan Agama Islam AlThariqah 2.1 (2017): 51-72. https://doi.org/10.25299/althariqa h.2017.vol2(1).647.

Ahmad, Mawardi, and Syahraini Tambak. "Penerapan Metode Diskusi Dalam Meningkatkan Hasil Belajar Murid Pada Pelajaran Fiqh." Al-Hikmah: Jurnal Agama Dan Ilmu Pengetahuan 15.1 (2018): 64-84. https://doi.org/10.25299/jaip.2018. vol15(1).1585.

Al-Munawar, Said Agil Husain, Syahraini Tambak, and Umi Kalsum. Aktualisasi nilai-nilai Qu'rani dalam sistem pendidikan Islam. Ciputat Press, 2003. Arisanti, Devi. "Manajemen Lingkungan Pendidikan Dalam Perspektif Islam." Jurnal Pendidikan Agama Islam AlThariqah 1.1 (2016): 71-86. doi:https://doi.org/10.25299/althari qah.2016.vol1(1).620.

Efferi, Adri. "Mengelola Lembaga Pendidikan Di Era Global (Pergeseran Paradigma Humanis Menjadi Bisnis)." QUALITY: Jurnal Pendidikan Islaman 3.1 (2015): 1-19. doi:http://dx.doi.org/10.21043/quali ty.v3i1.1170.

Fatmawati, Eva. "Manajemen Pembelajaran Tahfidz Al-Qur'an." Jurnal Islamic Education Manajemen $4, .1$ ((2019): 25-38. doi:10.15575/isema.v3i2.5255.

Gunawan, Imam, and Djum-Djum Noor Benty. Manajemen Pendidikan. 2017.

Hakim, Abdul, and N. Hani Herlina. "Manajemen Kurikulum Terpadu Di Pondok Pesantren Modern Daarul Huda Banjar." Jurnal Penelitian Pendidikan Islam 6. 1 (2018): 11-32. doi:https://doi.org/10.36667/jppi.v6 i1.157.

Hamzah, Desi Sukenti, Syahraini Tambak, and Wisudatul Ummi Tanjung. "Overcoming self-confidence of Islamic religious education students: The influence of personal learning model." Journal of Education and Learning (EduLearn) 14.4 (2020): 582-589.

https://doi.org/10.11591/edulearn. v14i4.16759.

Hamzah, Hamzah, Syahraini Tambak, and Nella Ariyani. "Upaya Guru Pendidikan Agama Islam dalam Pembentukan Kepribadian Islam Siswa di SMA Negeri 2 Kelayang Kabupaten Indragiri Hulu." AlHikmah: Jurnal Agama dan Ilmu Pengetahuan 14.1 (2017): 76-95. https://doi.org/10.25299/alhikmah:jaip.2017.vol14(1).1528.

Inayati, Isna Nurul, et al. "Pengaruh Lingkungan Pesantren Terhadap Kedisiplinan Siswa Kelas XII Madrasah Aliyah Miftahul Huda." Tarbiyatuna. 4. 1 (2020): 48-60. doi:https://doi.org/10.29062/tarbiy atuna.v4i1.304.

Inayati, Nurul Latifatul, and Aisyah Safina. "Manajemen Pembelajaran Tahfidzul Qur'an Santriwati Pondok Pesantren Islam Al- Mukmin Sukoharjo." SUHUF 31.1 (2019): 13-42.

Nasional, Departemen Pendidikan. "Teropong Pendidikan Kita." Jakarta: Pusat Informasi dan Humas Departemen Pendidikan Nasional (2006).

Noer, Ali, Syahraini Tambak, and Harun Rahman. "Upaya Ekstrakurikuler Kerohanian Islam (ROHIS) dalam Meningkatkan Sikap Keberagamaan 
Siswa di SMK Ibnu Taimiyah Pekanbaru." Jurnal Pendidikan Agama Islam Al-Thariqah 2.1 (2017): 21-38. https://doi.org/10.25299/althariqah. 2017.vol2(1).645.

Rahmawati, Alvi Dyah. "Manajemen Pengorganisasian Program Kursus Bahasa Arab Di Pare Kediri." Arabi: Journal of Arabic Studies 3.1 (2018): 52-60. doi:10.24865/ajas.v3i1.71.

Romdoni, Lisda Nurul, and Elly Malihah. "Membangun Pendidikan Karakter Santri Melalui Panca Jiwa Pondok Pesantren." Jurnal Pendidikan Agama Islam Al-Thariqah 5.2 (2020): 13-22. doi:https://doi.org/10.25299/althariqah.2020.vol5(2).4808.

Rukajat, Ajat. Manajemen Pembelajaran. Deepublish, 2018.

Saefrudin. "Pengorganisasian Dalam Manajemen." Alhikmah 5.2 (2017): 178-182.

Siregar, Muammar Kadafi. "Pondok Pesantren Antara Misi Melahirkan Ulama Dan Tarikan Modernisasi." Jurnal Pendidikan Agama Islam AlThariqah 3.2 (2018): 16-27. doi:https://doi.org/10.25299/althari qah.2018.vol3(2).2263.

Skinner. Ilmu Pengetahuan Dan Perilaku Manusia. Pustaka Pelajar, 2013.

Sugiyono. Metode Penelitian Pendidikan Pendekatan Kuantitatif, Kualitatif, Dan R\&D. 22nd ed., 2015.

Suhendri. "Manajemen Pembelajaran PAI Bagi Anak Berkebutuhan Khusus Di SLB Kota Medan." Sabilurrasyad 2.2 (2017): 121-134.

Sukenti, Desi, and Syahraini Tambak. "Developing Indonesian Language Learning Assessments: Strengthening the Personal Competence and Islamic Psychosocial

Teachers." International Journal of Evaluation and Research in Education 9.4 (2020): 1079-1087.

Sukenti, Desi, and Syahraini Tambak. "Strengthening Islamic Psychosocial and Self-confidence in Develophing Student Thinking Creative." ICOSEEH
20194 (2019): 446-453.

Suryapermana, Nana. "Manajemen

Pembelajaran Dalam Dunia Pendidikan." An-Nidhom Uurnal Manajemen Pendidikan Islam) 1.2 (2016): 73-90.

Syafaruddin. Manajemen Pembelajaran. Quantum Teaching, 2005.

Syafe'i, Imam. "Pondok Pesantren: Lembaga Pendidikan Pembentukan Karakter." Al-Tadzkiyyah: Jurnal Pendidikan Islam 8.1 (2017): 61-82. doi:https://doi.org/10.24042/atjpi.v 8i1.2097.

Tambak, Syahraini. "SejarahPendidikan Islam: PadaPeriodeKlasikdanPerte ngahan,(ed) Abuddin Nata." Jakarta: Raja GrafindoPersada, Cet II (2010).

Tambak, Syahraini, et al. "Internalization of Riau Malay Culture in Developing the Morals of Madrasah Ibtidaiyah Students." Al Ibtida: Jurnal Pendidikan Guru MI 7.1 (2020): 6984.

https://doi.org/10.24235/al.ibtida.s nj.v7i1.5954.

Tambak, Syahraini, and Desi Sukenti. "Pengembangan profesionalisme guru madrasah dengan penguatan konsep khalifah." Hayula: Indonesian Journal of Multidisciplinary Islamic Studies 4.1 (2020): 41-66. https://doi.org/10.21009/004.01.0.

Tambak, Syahraini, Muhammad Ali Noer, Siti Humairoh, and Mawardi Ahmad. "Internalization of Riau Malay Culture in Developing the Morals of Madrasah Ibtidaiyah Students." $A l$ Ibtida: Jurnal Pendidikan Guru MI 7.1 (2020): 69-84

Tambak, Syahraini, and Desi Sukenti. "Strengthening Islamic behavior and Islamic psychosocial in developing professional madrasah teachers." Cakrawala Pendidikan: Jurnal Ilmiah Pendidikan 39.1 (2020): 65-78.

Tambak, Syahraini. "Pendidikan Etika Bergaul Islami Dalam Keluarga "Nilai Pendidikan Etika Berlaku Adil Orangtua dengan Anak dalam 
Pergaulan Keluarga Perspektif Hadits"." Jurnal Pendidikan Agama Islam Al-Thariqah 4.1 (2019): 1-20. https://doi.org/10.25299/althariqah.2019.vol4(1).2910.

Tambak, Syahraini, et al. "Profesionalisme Guru Madrasah: Internalisasi Nilai Islam dalam Mengembangkan Akhlak Aktual Siswa." Jurnal Pendidikan Agama Islam Al-Thariqah 5.2 (2020): 79-96. https://doi.org/10.25299/althariqah.2020.vol5(2).5885.

Tambak, Syahraini, Amril M, Zuriatul Khairi, and Desi Sukenti. "Development of Madrasah Teacher Professionalism by Strengthening the Khalifah Concept and Islamic Psychosocial Perspective." International Conference on Islamic Education (ICIE 2018). Atlantis Press, 2018. https://doi.org/10.2991/icie18.2018.7.

Tambak, Syahraini. "Filsafat Idealisme dan Implikasinya pada Teori Pendidikan." Al-Hikmah 11.1 (2014): 61-75.
Tambak, Syahraini, M. Yusuf Ahmad, and Desi Sukenti. "Strengthening Emotional Intelligence in Developing the Madrasah Teachers' Professionalism (Penguatan Kecerdasan Emosional dalam Mengembangkan Profesionalisme Guru Madrasah)." Akademika 90.2 (2020). https://doi.org/10.17576/akad2020-9002-03.

Tambak, Syahraini. "Jihad Pendidikan: Konsep dan Upaya Memajukan Pendidikan Indonesia." AlHikmah 7.14 (2010): 1-15.

Tambak, Syahraini. "Pendidikan Agama Islam; Konsep Metode Pembelajaran PAI." (2014).

Widayati, Yuni. "Manajemen Pembelajaran Kebahasaan Dalam Upaya Meningkatkan Mutu Lulusan Di MAN 2 Yogyakarta." Media Manajemen Pendidikan 1.1 (2018): 78-86. doi:10.30738/mmp.v1i1.2896. 